\title{
PENGARUH BUDAYA ORGANISASI TERHADAP KINERJA USAHA KECIL
}

\author{
Rohmat Dwi Jatmiko \\ Fakultas Ekonomi dan Bisnis \\ Universitas Muhammadiyah Malang
}

Penelitian tentang ciri budaya organisasi yang berkembang dikaitkan dengan kinerja Usaha Kecil (UK) belum banyak dilakukan. Penelitian bertujuan menganalisa dan menguji pengaruh ciri budaya organisasi terhadap kinerja UK. Analisis SEM menemukan adanya ambiguitas orientasi system ciri budaya antara "adaptability" yang fleksibel terhadap lingkungan eksternal dengan ciri budaya "consistency" yang cenderung mengendalikan stabilitas internal yang kuat dan kurang fleksibel terhadap lingkungan, dan terjadi dysfunctional culture karena budaya organisasi berpengaruh lemah positip signifikan terhadap kinerja UK.

Keywords:

Budaya organisasi, dysfuctional culture, ambiguitas sistem budaya, kinerja 


\section{PENDAHULUAN}

Schein (1992) menyatakan bahwa "satu hal yang sangat penting yang harus dilakukan para pemimpin adalah menciptakan dan mengelola budaya" dan "bakat paling unik dari para pemimpin adalah kemampuannya untuk memahami dan bekerja di dalam budaya tersebut". Menurut Schein (1992), para pemimpin harus mampu menilai seberapa tepat budaya organisasi yang sedang berlaku, serta menentukan kapan dan bagaimana budaya organisasi perlu dirubah. Menilai dan memperbaiki budaya organisasi serta penentuan kapan diperlukan transformasi budaya sangat menentukan kinerja jangka panjang organisasi. Deal dan Kennedy (1982) menyatakan bahwa budaya merupakan faktor penting untuk keberhasilan organisasi. Budaya organisasi muncul sebagai faktor yang memiliki potensi besar untuk mempengaruhi dan mempertahankan kinerja organisasi. Scott et al. (2003) menyatakan bahwa pengelolaan budaya organisasi dipandang sebagai bagian penting untuk memperbaiki kinerja organisasi. Scott et al. (2003) menemukan bahwa budaya organisasi dapat mendorong dan membangun mekanisme organisasi yang efektif dan efisien, mempengaruhi tujuan ekonomi dan sosial, serta dapat mendorong hubungan dan kerjasama diantara anggota organisasi.

Budaya organisasi telah menjadi konsep penting dalam menjalankan bisnis (Deal and Kennedy, 1982; Denison, 1990). Budaya organisasi begitu penting karena merupakan aset bisnis yang memiliki potensi besar dampaknya terhadap kinerja organisasi (Musselwhite, 1999); organisasi perlu mengenali "siapa dirinya” melalui pemahaman terhadap ciri budaya organisasinya agar memiliki kemampuan untuk intervensi upaya peningkatan kinerja organisasi (Zwaan, 2006). Nier (2004) menyatakan bahwa meskipun budaya organisasi sering dilihat sebagai asset tidak berwujud, namun budaya organisasi memiliki pengaruh kuat karena dapat menjadi penghambat utama dalam mencapai sasaran-sasaran jangka panjang organisasi. Para pemikir budaya organisasi seperti Hofstede (2004); Cameron dan Quinn (1999); Denison (1997); Kotter dan Heskett (1992) mengemukakan bahwa budaya organisasi secara efektif mampu menjadi sumber keunggulan kompetitif dan mempengaruhi kinerja organisasi.

Kandula (2006) menyatakan bahwa kunci untuk kinerja yang baik adalah budaya yang kuat. Lebih lanjut Kandula menyatakan bahwa perbedaan budaya organisasi, strategi yang sama tidak menghasilkan kinerja yang sama untuk dua organisasi dalam industri yang sama dan di lokasi yang sama. Budaya yang positif dan kuat dapat membuat individu berkinerja di atas rata-rata dan kecemerlangan, sedang budaya negatif dan lemah mungkin dapat menurunkan motivasi karyawan yang cemerlang untuk berprestasi dan berakhir dengan tidak ada prestasi. Oleh karena itu budaya organisasi memiliki peran aktif dan langsung dalam kinerja.

Pemahaman komprehensif tentang budaya organisasi pada Usaha Kecil (selanjutnya disingkat UK) menjadi sangat penting terutama untuk memahami ciri budaya yang mendukung atau menghambat kinerja UK. Permasalahan yang selalu dihadapi UK adalah rendahnya kinerja dan tingginya tingkat kegagalan bisnis. Berbagai upaya telah banyak dilakukan untuk meningkatkan kinerja UK misalnya pemberian bantuan modal, bantuan peralatan, pelatihan manajemen, pelatihan pemasaran sering tidak berhasil sebagaimana yang diharapkan. Karena kinerja organisasi merupakan hasil dari sebuah sistem nilai yang berkembang pada organisasi tersebut. Kinerja perusahaan tidak sekedar ditentukan 
oleh aspek-aspek perangkat "keras (hard)" tersebut, tetapi juga oleh perangkat "lunak (soft)" yang menyangkut aspek-aspek perilaku dan budaya organisasi yang cenderung sulit dirubah. Aspek-aspek keras dianggap kurang mampu merubah kebiasaan, norma, dan nilai-nilai yang berkembang dan diyakini para pemilik/manajer dan karyawan UK. Implementasi dari aspek-aspek keras sulit berhasil tanpa dukungan perangkat "lunak" yang relevan di dalam suatu organisasi, diantaranya adalah budaya organisasi. Budaya organisasi tidak sekedar dipandang sebagai sarana untuk meningkatkan integrasi dan koordinasi internal, tetapi juga dipandang sebagai sistem terbuka suatu organisasi. Budaya organisasi diakui penting pengaruhnya terhadap kinerja organisasi karena kemampuannya memediasi organisasi dalam beradaptasi dengan lingkungannya. Oleh karena itu, penelitian ini berangkat dari pemahaman apakah orientasi sistem nilai dan norma atau budaya organisasi yang berkembang pada suatu organisasi menjadi salah satu faktor penentu keberhasilan dan kinerja UK.

McGarvey dan Wolfe (2000) mendukung upaya penelitian yang berkaitan dengan ciri tertentu dari budaya organisasi dengan keberhasilan atau kegagalan serta kinerja organisasi. Kajian tentang budaya organisasi dan pertanyaan apakah budaya memiliki pengaruh terhadap pengembangan dan kinerja organisasi menempati ruang yang memadai dalam literatur manajemen (Choueke dan Armstrong, 2000). Masih sedikit penelitian yang memfokuskan pada kajian tentang pemahaman ciri budaya organisasi yang berkembang dan pengaruhnya terhadap kinerja UK. Apabila ciri tertentu dari budaya organisasi mampu menjadi pendorong utama pengembangan organisasi dan kesuksesan pada perusahaanperusahaan besar, maka yang menjadi pertanyaan adalah apakah ciri tertentu dari budaya organisasi juga berkembang pada UK mampu menjadi pendorong kinerja UK. Karena itu, penelitian ini bertujuan menguji pengaruh budaya organisasi terhadap kinerja UK.

\section{TINJAUAN PUSTAKA}

\section{$2.1 \quad$ Budaya Organisasi}

Literatur tentang budaya organisasi memberikan inspirasi bahwa setiap organisasi memiliki kemungkinan dan kapasitas untuk berubah. Sama halnya dengan kepribadian individu manusia yang mengalami perubahan sebagai akibat dari interaksi dengan lingkungan sosial di sekitarnya, demikian pula dengan budaya organisasi (Salama dan Smith, 1994). Menurut Simpson dan Cacioppe (2001) budaya organisasi berfungsi: membedakan suatu organisasi dengan organisasi lainnya; memberikan identitas bagi para anggota organisasi; membangkitkan komitmen terhadap organisasi dan kelompok; dan sebagai perekat sosial (the social glue) yang berisi tentang apa yang harus dilakukan oleh para anggota organisasi. Budaya organisasi juga dapat membatasi kemampuan organisasi beradaptasi terhadap perubahan lingkungan, misalnya organisasi gagal merespon perubahan pasar karena budaya internalnya tidak memberi prioritas utama pada pelayanan pelanggan.

Untuk keperluan analisis budaya suatu organisasi, para peneliti dan pemikir budaya organisasi telah melakukan penggolongan ciri budaya. Sonnenfeld (1998) dalam Sadri dan Lees (2001) menggolongkan empat tipe budaya organisasi, yaitu: akademi, club, tim baseball, dan benteng (fortress). Lomas (1999) menggolongkan budaya organisasi kedalam empat ciri, yaitu budaya kolegial, budaya birokratik, budaya entrepreneurial, 
dan budaya korporat. Cornwall (1990) membedakan 2 (dua) tipe budaya organisasi, yaitu budaya organisasi tradisional (traditional organizational culture) dan budaya organisasi entrepreneurial (entrepreneurial organizational culture). Denison (1997) menggolongkan empat ciri budaya organisasi, yaitu mission, consistency, adaptability, dan involvement.

Mission adalah derajad dimana organisasi dan para anggotanya mengetahui kemana mereka akan menuju, bagaimana mereka akan mencapainya, dan bagaimana setiap individu dapat memberikan kontribusi terhadap keberhasilan organisasi (Adkins dan Steward, 1999). Atribut-atribut mission mencakup: Vision, strategic direction and intent, and goals and objectives. Consistency adalah nilai-nilai inti (core values) dan sistem internal organisasi yang mendukung penyelesaian masalah, efisiensi, dan efektivitas setiap tingkatan dan lintas fungsi dalam organisasi (Adkins dan Steward 1999). Atribut-atribut consistency mencakup: coordination and integration, agreement, and core values. Involvement adalah derajad dimana para individu pada setiap tingkatan organisasi didorong untuk merasa ikut memiliki dan rasa tanggungjawab, serta dilibatkan dalam mewujudkan missi dan bekerjasama dalam bekerja untuk mencapai sasaran-sasaran organisasi (Adkins dan Steward 1999). Atribut-atribut involvement mencakup: capability development, team orientation, and empowerment (Fey dan Denison, 2000). Adaptability adalah kemampuan perusahaan untuk melihat dan merespon perubahan lingkungan eksternal, terutama perubahan kebutuhan pelanggan dan stakeholders lainnya kedalam tindakan nyata (Adkins dan Steward 1999). Atributatribut adaptability mencakup: creating change, customer focus, and organizational learning.
Denison merancang suatu instrumen untuk memetakan ciri budaya organisasi yang kemudian dikenal sebagai Denison Organizational Culture Survey (DOCS). DOCS dapat digunakan untuk menilai ciri dan kuat-lemahnya budaya suatu organisasi. Dalam DOCS terdapat 4 (empat) kuadran yang menggambarkan ciri budaya organisasi, yaitu: mission, consistency, adaptability, dan involvement. Setiap kuadran terdapat tiga indeks praktek-praktek manajerial yang dikaitkan dengan ciri budaya. Ciri-ciri budaya dan indeks disajikan dalam dua dimensi, yaitu: flexibility versus stability pada sumbu horisontal, dan external focus versus internal focus pada sumbu vertikal. Model untuk mengenali ciri-ciri budaya, perilaku managerial, dan strategi organisasi dapat dikaitkan pada inti dari keyakinan dan asumsi-asumsi yang berkaitan dengan organisasi dan lingkungannya.

Involvement dan Consistency menunjukkan dinamika internal organisasi, namun tidak menunjukkan interaksi organisasi dengan lingkungan eksternalnya. Sementara Adaptability dan Mission menggambarkan dinamika organisasi dengan lingkungan eksternalnya. Involvement dan Adaptability menekankan kapasitas organisasi pada fleksibilitas dan perubahan. Sebaliknya, Consistency dan Mission menekankan kapasitas organisasi pada stabilitas dan direction. Orientasi sistem ke arah Adaptability dan Involvement mengintrodusir banyak variasi, banyak input, dan banyak kemungkinan solusi berdasarkan pada situasi yang sedang terjadi dari pada orientasi sistem yang mengarah pada consistency tinggi dan misi yang kuat. Sebalikya, condong (bias) ke arah Consistency dan Mission kemungkinan lebih mengurangi variasi dan lebih memperhatikan pada pengendalian dan stabilitas. Dengan pengertian serupa, ciri budaya ke arah mission dan involvement juga memiliki 
kontradiksi: makna dan arah dibentuk oleh misi organisasi dapat membatasi keterlibatan beberapa anggota organisasi. Banyak organisasi yang sudah terungkap, perumusan misi organisasi tidak mesti menyiratkan komitmen dan dukungan dari para anggota organisasi. Demikian pula, komitmen tinggi diantara para anggota organisasi tidak mesti menyiratkan suatu pengertian arah dan tujuan yang jelas tentang organisasi.

Penelitian Denison menunjukkan bahwa budaya suatu organisasi yang efektif harus mencerminkan semua karakteristik dari ciri budaya. Dengan demikian, organisasi yang efektif memungkinkan untuk mempunyai budaya yang adaptip, pada saat yang bersamaan memiliki konsistensi tinggi dan dapat diprediksi, serta mampu mengembangkan involvement atau keterlibatan tinggi, tetapi tetap harus di dalam konteks perasaan yang sama terhadap misi organisasi. Untuk menjawab pertanyaan ciri budaya yang seperti apakah yang berkembang pada UK maka digunakan teori Denison Organizational Culture Survey (DOCS) yang dikembangkan oleh Denison (1997). DOCS digunakan untuk menilai budaya organisasi yang berkembang pada UK karena dalam menilai budaya organisasi yang berkembang, DOCS mengkaitkan situasi internal dan eksternal organisasi.

\subsection{Kinerja Perusahaan}

Kinerja atau hasil akhir (end results) aktivitas organisasi biasanya diukur dalam bentuk kinerja (performance) kuantitatif maupun kualitatif produk/jasa, kepuasan pelanggan, serta kepuasan karyawan yang diukur tingkat absenteisme dan turnover karyawan; pertumbuhan dan pengembangan personal (Newstrom dan Davis, 2002). Kinerja perusahaan merupakan fenomena multi-aspek yang sulit diukur. Sanchez dan Marin (2005) menyatakan bahwa kinerja organisasi, baik indikator kuantitatif maupun kualitatif, memiliki keterbatasan tertentu dan direkomendasikan untuk digunakan secara kombinasi. Pengukuran kuantitatif seperti Return on Investment (ROI), profit, sales, dan sebagainya. Sedang pengukuran kinerja yang bersifat kualitatif merupakan pengukuran kinerja dengan menggunakan pendekatan skala tertentu atas indikatorindikator kinerja seperti: pengetahuan dan pengalaman bisnis; kemampuan untuk menawarkan kualitas produk atau jasa; kapasitas untuk mengembangkan proses dan produk baru; kemampuan mengelola dan bekerja dalam kelompok; produktivitas tenaga kerja; dan tanggungjawab perusahaan terhadap lingkungannya.

Verreynne (2005) mengukur kinerja usaha kecil dan menengah (UKM) dengan menggunakan ukuran-ukuran skala kinerja finansial yang dikembangkan oleh Gupta dan Govindarajan (1984) dalam Kotey dan Meredith (1997) yang tujuan utamanya untuk mendiskripsikan keterbatasan data finansial dalam pengukuran kinerja UKM. Prosedur pengukuran kinerja UKM menurut Gupta dan Govindarajan (1984), mencakup penilaian responden berdasarkan skala Likert terhadap ukuran-ukuran finansial yang mencakup tingkat penjualan, tingkat pertumbuhan penjualan, arus kas, tingkat pengembalian modal sendiri, margin laba kotor, laba bersih operasi, rasio laba atas penjualan, tingkat pengembalian modal, kemampuan membiayai pertumbuhan perusahaan dari laba, serta kinerja secara keseluruhan. Menurut Kotey dan Meredith (1997) metode pengukuran kinerja Gupta dan Govindarajan ternyata memiliki tingkat reliabilitas dan validitas yang tinggi, hal ini merefleksikan keakuratan pengukuran kinerja perusahaan.

Cunha et al., mengukur kinerja UKM berdasarkan penjualan kotor yang dicapai pada periode tertentu. Kinerja UKM diukur melalui satu pertanyaan yang 
meminta responden untuk mengungkapkan penjualan kotornya yang dirasakan perusahaan selama periode tertentu (misal tiga tahun terakhir), pada skala 5 titik ( $1=$ sangat rendah bagaikan memperolah kerugian besar; 2 = tidak cukup untuk menutup biaya; 3 = cukup, namun hanya mencapai titik impas; $4=$ cukup, menghasilkan laba kecil, dan 5 = besar dan melebihi biaya-biaya yang dikeluarkan). Pemilihan pengukuran subyektif atas kinerja organisasi didasarkan pada fakta bahwa di dalam banyak survei pada UKM, pengukuran kinerja obyektif ada bahayanya, karena sistem akuntansinya belum baik dan laporan keuangan yang tidak komparabel. Terdapat korelasi kuat antara respon subyektif dan pengukuran obyektif atas kinerja organisasi telah pula ditemukan. Dalam keadaan seperti ini, persepsi mengenai kinerja perusahaan dan kesuksesan keuangan suatu organisasi mungkin samasama efektifnya dengan pengukuranpengukuran "obyektif" seperti ukuran laba, atau ROI.

\subsection{Budaya Organisasi - Kinerja Perusahaan}

Rashid et al., (2003) menyatakan bahwa budaya organisasi memiliki potensi pengaruh terhadap kinerja organisasi. Simpson dan Cacioppe (2001) menyatakan bahwa budaya korporasi memiliki dampak jangka panjang terhadap kinerja organisasi dan kualitas layanan kepada pelanggan. Denison (1990) menyatakan bahwa ciri tertentu dari budaya organisasi dapat meningkatkan kinerja organisasi. Menurut Porter (1980) perusahaan-perusahaan yang sukses, yaitu perusahaan-perusahaan yang secara terus menerus mendapatkan keuntungan dan laba di atas normal, adalah perusahaan yang berada pada enam kondisi. Pertama, perusahaan yang berada pada industri/pasar yang memiliki hambatan masuk yang tinggi. Kedua, tidak adanya produk substitusi. Ketiga, menggunakan skala ekonomi yang efisien. Keempat, kekuatan tawar para pembeli rendah. Kelima, kekuatan tawar para pemasok rendah. Dan terakhir, rival diantara para pesaing. Namun, menurut Cameron dan Quinn (1999) tidak dapat diragukan bahwa banyak perusahaan yang sukses dan memiliki kinerja finansial yang baik bukan karena faktor atau kondisi sebagaimana diungkapkan oleh Porter. Banyak perusahaan yang memiliki keunggulan kompetitif dan sukses luar biasa karena memiliki faktor yang lebih mujarab (powerfull) yaitu budaya organisasi. Banyak peneliti dan pengamat organisasi yang mengakui bahwa budaya organisasi memiliki pengaruh sangat kuat terhadap kinerja dan efektifitas jangka panjang organisasi.

Fey dan Denison (2000) meneliti korelasi antara ciri budaya organisasi yang mencakup mission, consistency, involvement, dan adaptability dengan ukuran-ukuran efektivitas dan kinerja organisasi. Kinerja organisasi yang digunakan mencakup Return on Assets, Return on Investment, sales growth, market share, kualitas dan kepuasan karyawan. Fey dan Denison menemukan bahwa terdapat korelasi yang signifikan antara ciri budaya organisasi dengan kinerja organisasi. Berdasar temuan Fey dan Denison ini maka dapat dipahami bagaimana ciri tertentu dari budaya organisasi dapat mempengaruhi ukuran-ukuran kinerja spesifik dan kinerja organisasi secara keseluruhan. Namun, menurut Van den Steen (2005) hubungan antara budaya organisasi dan kinerja perusahaan kurang konsisten. Ketidak-konsistenan ini karena hubungan antara budaya dan kinerja organisasi sangat bergantung pada kondisi lingkungannya. Lebih lanjut Steen menyatakan bahwa banyak organisasi beroperasi dalam lingkungan yang dinamis, pandangan ini 
menunjukkan bahwa budaya yang kuat dapat mengurangi kinerja perusahaan.

Kinerja suatu perusahaan ditentukan oleh strategi bisnis yang diadopsi. Sementara itu, keberhasilan implementasi strategi sangat ditentukan oleh budaya organisasinya. Dengan kata lain, nilai-nilai dan keyakinankeyakinan di dalam organisasi akan menentukan bagaimana organisasi dijalankan dan kinerjanya (Paige, 2005). Budaya kuat dapat membangkitkan komitmen terhadap nilai-nilai organisasi. Menurut Suda (2007) budaya kuat dapat menjadi sarana bagi organisasi untuk memperkuat kinerjanya, mengubah dan menyesuaikan perubahan lingkungan, untuk terus mempertahankan kelangsungan hidupnya serta mempertahankan kinerja kompetitifnya. Menurut Turunen (2007), budaya kuat pada umumnya dikenalkan dan mempunyai powerful effect secara luas kepada para karyawan, menunjukkan apa yang benar dan yang salah, memandu setiap orang ke arah yang benar, memberikan struktur yang diperlukan dan memperjelas kendali keseluruhan proses, dapat membatasi manajemen dari keinginan untuk selalu merubah budaya. Budaya kuat dipertimbangkan sebagai prediktor kinerja superior masa depan organisasi. Salah satu hal penting namun relatip sedikit dipahami adalah pertanyaan apakah budaya organisasi berhubungan dengan kinerja organisasi pada UK. Menurut Barney (1986), para peneliti awalnya menemukan hubungan langsung positif dan berspekulasi bahwa beberapa tipe budaya tertentu menyebabkan kinerja keuangan yang lebih baik. Logikanya adalah bahwa apabila norma-norma yang disepakati bersama ditegakkan dengan kuat diantara para anggota akan meningkatkan aliansi strategis dan pencapaian tujuan yang lebih besar dalam perusahaan-perusahaan yang memiliki budaya kuat.
Hipotesis: Usaha Kecil yang memiliki budaya organisasi yang kuat, maka kinerjanya akan semakin tinggi.

\section{METODE PENELITIAN}

Desain penelitian adalah eksplanatif berdasarkan data survey. Populasi penelitian adalah 1.385 UK yang bergerak di bidang manufaktur, pengolahan, kerajinan, logam, serta makanan dan minuman yang sekurangkurangnya mempekerjakan 5 (lima) orang karyawan, telah memiliki Surat Ijin Usaha Perdagangan (SIUP) di Kabupaten Magetan, Pacitan, dan Ponorogo. Unit analisisnya adalah para pemilik UK dari sampel sebanyak 400 unit UK yang dihitung berdasarkan pendekatan Slovin (Widayat, 2002). Variabilitas UK dilihat dari sisi jumlah dalam setiap sentra industri, umur perusahaan, pengalaman mengelola bisnis, dan perbedaan industri sangat beragam. Karena itu, teknik sampling yang digunakan adalah disproportionate stratified random sampling (Kinnear dan Taylor, 1995). Data diperoleh berdasarkan respon para pemilik UK yang terpilih sebagai sampel terhadap item-item pernyataan dalam kuisioner. Pemilik UK diminta mengungkapkan responnya terhadap 24 (dua puluh empat) item pernyataan untuk mengukur budaya organisasi berdasarkan skala Likert 5 (lima) titik dari 1 (satu) "Sangat Tidak Setuju (STS) sampai dengan 5 (lima) Sangat Setuju (SS)”.

Budaya organisasi dalam penelitian ini didefinisikan sebagai seperangkat nilai, keyakinan, dan pandangan hidup organisasi yang dijiwai, dipahami, dan dipraktekkan oleh para pemilik dan karyawan UK untuk bertindak dan berperilaku dalam mengelola organisasi. Budaya organisasi UK diukur berdasarkan konsep Denison Oganizational Culture Survey (DOCS) yang terdiri dari 4 (empat) ciri budaya, yaitu involvement, consistency, adaptability, dan mission. 
Mission adalah derajad dimana pemilik UK memahami apa yang menjadi tujuannya, bagaimana mencapainya, dan bagaimana setiap individu (pemilik dan karyawan) mampu memberikan kontribusi terhadap keberhasilan perusahaannya. Indikator ciri budaya mission mencakup vision, strategic direction and intent, serta goals and objectives. Vision diukur berdasarkan: jangkauan pemikiran tentang masa depan perusahaan, dan kemampuan UK memenuhi tuntutan perubahan jangka panjang. Strategic direction and intent diukur berdasarkan: kejelasan misi perusahaan, dan strategi bersaing perusahaan. Goals and objectives diukur berdasarkan penetapan tujuan perusahaan oleh pemilik, dan pemahaman karyawan tentang masa depan perusahaan.

Consistency adalah nilai-nilai inti dan sistem internal yang mampu mendukung penyelesaian masalah, efisiensi, dan efektivitas UK. Indikator ciri budaya consistency mencakup coordination and integration, agreement, dan core values. Coordination and integration diukur berdasarkan: persamaan perspektif dari setiap orang di dalam perusahaan, dan kemudahaan dalam pelaksanaan koordinasi. Agreement diukur berdasarkan: upaya pemilik UK untuk mencapai penyelesaian yang saling menguntungkan bila terjadi perselisihan, adanya kesepakatan antara perusahaan dan karyawan apabila perusahaan atau karyawan melakukan kesalahan. Core values diukur berdasarkan: ada-tidaknya pedoman yang jelas dan konsisten tentang bagaimana mengelola perusahaan, dan peraturan yang dapat menjadi pedoman perilaku karyawan.

Involvement adalah derajad dimana para pemilik dan karyawan UK terlibat dan dilibatkan dalam mewujudkan missi perusahaan, dan bekerjasama dalam bekerja untuk mencapai sasaran-sasaran organisasi. Indikator ciri budaya involvement mencakup: empowerment, team orientation, dan capability development. Empowerment diukur berdasarkan: keterlibatan karyawan dalam pekerjaannya, dan keyakinan karyawan tentang pengaruhnya terhadap kinerja perusahaan. Team orientation diukur berdasarkan: keaktifan karyawan dalam team kerja, dan pengertian karyawan tentang kaitan pekerjaannya dengan tujuan perusahaan. Capability development diukur berdasarkan: kewenangan karyawan dalam mengambil keputusan tentang pekerjaannya, dan upaya perusahaan meningkatkan ketrampilan karyawan.

Adaptability adalah kemampuan UK melihat dan merespon perubahan lingkungan eksternal, terutama perubahan keinginan dan kebutuhan pelanggan. Indikator ciri budaya adaptability mencakup: creating change, customer focus, dan organizational learning. Creating change diukur berdasarkan: kemampuan UK menyesuaikan diri terhadap perubahan lingkungan, dan daya tanggap UK terhadap perubahan lingkungan. Customer focus diukur berdasarkan: keterbukaan UK terhadap saran dari pelanggan, dan tingkat pemahaman karyawan tentang keinginan dan kebutuhan pelanggan. Organizational learning diukur berdasarkan: kesempatan karyawan untuk melakukan inovasi, dan pandangan pemilik UK tentang kegagalan/keberhasilan di masa lalu.

Kinerja UK didefinisikan sebagai hasil akhir atau outcome yang dihasilkan dari aktivitas UK dalam kurun waktu tertentu. Kinerja UK diukur melalui satu pertanyaan yang meminta pemilik UK untuk mengungkapkan penjualan kotornya yang dirasakan selama periode tiga tahun terakhir pada skala 5 titik $(1=$ sangat rendah bagaikan memperolah kerugian besar; 2 = tidak cukup untuk menutup biaya; 3 = cukup, namun hanya mencapai titik impas; $4=$ cukup, menghasilkan laba kecil, dan $5=$ besar dan melebihi biaya-biaya yang 
dikeluarkan). Kinerja UK juga diukur berdasarkan persepsi pemilik UK tentang penyerapan tenaga kerja, pertumbuhan penjualan, serta posisi persaingan perusahaannya dalam kurun waktu tiga tahun terakhir. Pemilihan pengukuran subyektif (berdasarkan persepsi pemilik UK) atas kinerja UK didasarkan pada asumsi bahwa di dalam UK pengukuran kinerja obyektif sulit dilakukan karena sistem akuntansinya belum baik dan laporan keuangan yang tidak komparabel. Berikut variabel, ciri dan indikator penelitian pada Tabel 1.

Tabel 1.

Variabel, Ciri/Dimensi dan Indikator Penelitian

\begin{tabular}{|c|c|c|c|}
\hline Variabel & Ciri/Dimensi & Indikator & Skala \\
\hline \multirow{4}{*}{$\begin{array}{l}\text { Budaya } \\
\text { Organisasi }\end{array}$} & Mission & $\begin{array}{l}\text { - vision } \\
\text { - strategic direction and intent } \\
\text { - Goals and objectives } \\
\end{array}$ & \multirow{4}{*}{ Likert 5 titik } \\
\hline & Consistency & $\begin{array}{l}\text { - Coordination and integration } \\
\text { - Agreement } \\
\text { - Core values } \\
\end{array}$ & \\
\hline & Involvement & $\begin{array}{l}\text { - Empowerment } \\
\text { - Team orientation } \\
\text { - Capability development } \\
\end{array}$ & \\
\hline & Adaptability & $\begin{array}{l}\text { - Creating change } \\
\text { - Customer focus } \\
\text { - Organizational learning } \\
\end{array}$ & \\
\hline \multirow{4}{*}{ Kinerja UK } & Penjualan & Hasil penjualan tiga tahun terakhir & \multirow{4}{*}{ Likert 5 titik } \\
\hline & Posisi pasar & $\begin{array}{l}\text { Kekuatan persaingan yang dirasakan tiga } \\
\text { tahun terakhir }\end{array}$ & \\
\hline & $\begin{array}{l}\text { Pertumbuhan } \\
\text { penjualan }\end{array}$ & Pertumbuhan penjualan tiga tahun terakhir & \\
\hline & Tenaga kerja & $\begin{array}{l}\text { Pertumbuhan tenaga kerja tiga tahun } \\
\text { terakhir }\end{array}$ & \\
\hline
\end{tabular}

Metode analisis untuk menguji hipotesis adalah Structural Equation Modeling (SEM) dengan bantuan AMOS Versi 5.0. Structural model fit dievaluasi berdasarkan Hair et al., (2006) bahwa dalam menilai overall structural model fit menekankan pada penggunaan lebih dari satu kesesuaian statistik (fit statistic) dengan merekomendasikan satu index absolut, satu incremental index, dan model $X^{2}$. Hair et al., (2006) menekankan bahwa salah satu dari fit indices should be a badness of fit index dan tidak ada keharusan bahwa semua good fit harus "fit" dalam semua situasi. Model $X^{2}$,
CMIN/DF, dan CFI digunakan sebagai ukuran overall fit sebagaimana yang direkomendasikan oleh Hair et al., (2006:857). Model $X^{2}$ (Khai-Kuadrat) dalam AMOS versi 5.0 dinamakan CMIN dengan significant p-values can be expected untuk sample di atas 250 dengan jumlah variabel observasi lebih dari 30, cut-of value dari CMIN/DF adalah $\leq$ 2, cut-off value CFI adalah $\geq 0.90$ (Hair et al., 2006:753). 


\section{HASIL DAN PEMBAHASAN}

Kuisioner yang kembali sebanyak 372 buah (119 Magetan; 93 Pacitan; dan 160 Ponorogo) atau 93\% dari 400 kuisioner yang diedarkan langsung kepada pemilik UK. Dari 372 kuisioner yang kembali terdapat 365 kuisioner (Magetan 116; Pacitan 93; Ponorogo 156) atau 98\% yang jawabannya lengkap dan dapat diproses untuk dianalisis. Sehingga data yang akan dianalisa dan digunakan untuk menguji hipotesis sebanyak 365 unit analisis.

Asumsi-asumsi SEM sebagai metode statistik multivariat yang digunakan adalah normalitas dan multikoliniaritas. Normalitas-sebaran data mempunyai distribusi sesuai dengan kurva normal maka sampel yang diambil dapat digeneralisasikan untuk populasi. Menurut Solimun (2002) salah satu pendekatan untuk mengetahui ada tidaknya pencilan (outlier) adalah membandingkan standar deviasi dengan ratarata skor, bilamana standar deviasi lebih besar dari rata-rata skor merupakan indikasi terdapatnya data outliers. Uji normalitas ditemukan tidak ada nilai simpangan baku yang lebih besar dari nilai rata-rata skor item-item pengukuran. Multikolinearitas diuji dengan korelasi bivariate berdasarkan Pearson ditemukan tidak ada korelasi antar variabel yang tinggi di atas 0,9. Gambar 1 . merupakan hasil olah data dengan bantuan software AMOS Versi 5.0 untuk menguji hubungan kausal antara budaya organisasi dengan kinerja UK. Pengujian model struktural keseluruhan menghasilkan fitindices sebagaimana dalam Tabel 2. Dengan memperhatikan cut-off values maka model struktural yang menguji hubungan kausal antara konstruk budaya organisasi dan kinerja UK dapat dikatakan sebagai model struktural yang valid dan reliabel.

Tabel 2.

Hasil Evaluasi Goodness of Fit

\begin{tabular}{|l||c||c|c||}
\hline \multicolumn{1}{|c||}{ Goodness of Fit Index } & Cut-off Value & Hasil Model & Keterangan \\
\hline \hline Khai kuadrat (CMIN) & $\begin{array}{c}\text { Significant } \text { p-value can } \\
\text { be expected untuk } \\
\text { sampel di atas 250 (Hair } \\
\text { et al., 2006:753) }\end{array}$ & 199,89 & Baik \\
\hline \hline Derajat bebas (DF) & Mendekati nilai CMIN & 99 & Baik \\
\hline \hline CMIN/DF & $\leq 2$ & 2,01 & Baik \\
\hline \hline Probabilitas & Signifikan & Signifikan & Baik \\
\hline \hline GFI & $\geq 0.90$ & 0,94 & Baik \\
\hline \hline CFI & $\geq 0.90$ & 0,95 & Baik \\
\hline \hline TLI & $\geq 0.90$ & 0,94 & Baik \\
\hline RMR & $\begin{array}{c}\leq 0.08 \text { dengan CFI } \geq \\
\text { (Hair } \text { et al., } \\
2006: 753)\end{array}$ & 0,067 & Baik \\
\hline \hline RMSEA & $\begin{array}{c}\leq 0.07 \text { with CFI } \geq 0.90 \\
\text { (Hair } \text { et al., 2006:753) }\end{array}$ & 0,053 & Baik \\
\hline
\end{tabular}

Loading factor antara 0,66-0,85 (lebih besar dari 0,40), variance extracted
(VE) antara 0,50-0,58 (sama dan lebih besar dari 0,50), construct reliability (CR) antara 
0,86-0,89 (lebih besar dari 0,70) menunjukkan bahwa konstruk variabel budaya organisasi yang digunakan dalam penelitian ini adalah valid dan reliable, seperti terlihat pada Tabel 4. Sehingga dapat dinyatakan bahwa ciri budaya organisasi yang mencakup involvement, consistency, adapatability, dan mission memiliki unidimensional yang dapat diterima dan mampu membentuk konstruk budaya organisasi pada UK yang disurvei.

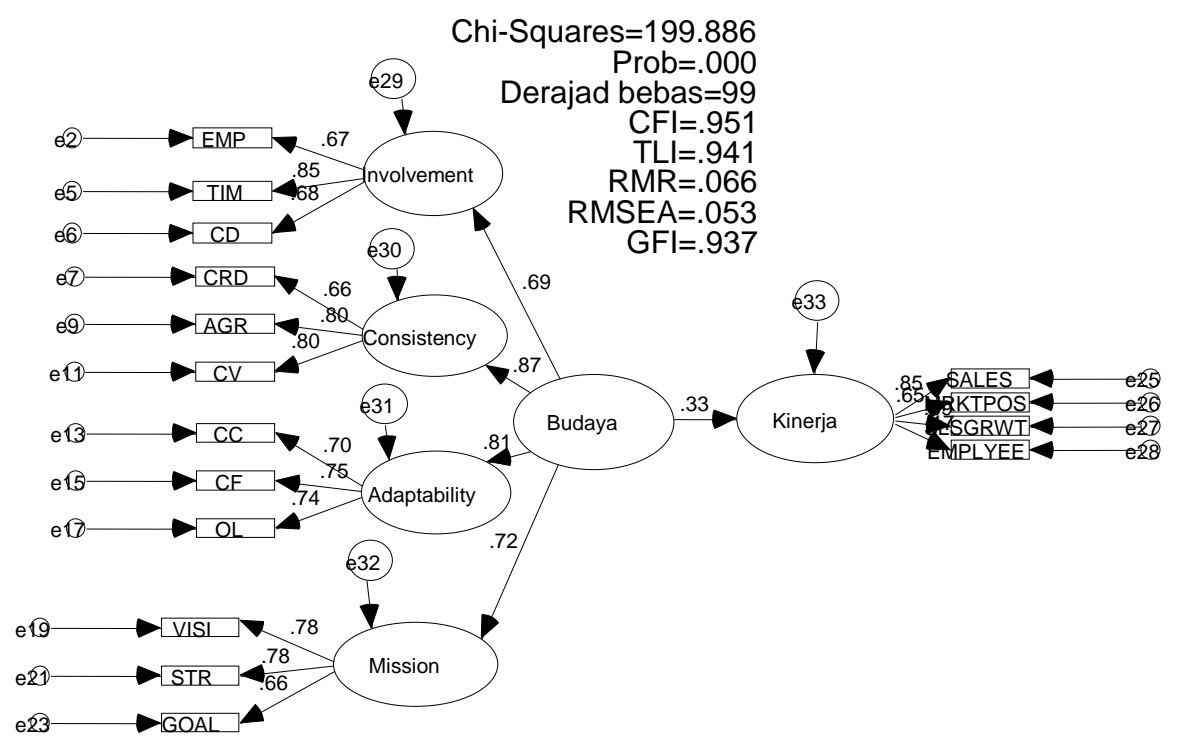

Gambar 1.

SEM Budaya Organisasi dan Kinerja UK

Pengujian atas hipotesis "Budaya Organisasi berpengaruh positip dan signifikan terhadap Kinerja UK” diperoleh loading factor 0,33 dengan critical ratio (CR) atau nilai-t sebesar 4,94 dan signifikan. Dengan demikian dapat dikatakan bahwa hipotesis teruji kebenarannya atau dapat diterima, seperti terlihat pada Tabel 3. Ciri budaya "consistency" dengan loading factor 0,87 dan "adaptability" dengan loading factor 0,81 merupakan ciri budaya yang memiliki derajad kepentingan paling tinggi dalam konstruk budaya organisasi UK yang disurvei, kemudian disusul secara berturutturut adalah dimensi mission $(0,70)$, dan yang paling rendah derajad kepentingannya adalah involvement $(0,66)$. Situasi demikian mengindikasikan bahwa UK yang disurvei memiliki orientasi budaya yang condong ke arah consistency dan adaptability.

Kecenderungan ke arah ciri budaya consistency dan adaptability mengindikasikan bahwa di dalam UK berkembang orientasi sistem budaya yang berlawanan. Temuan ini mengindikasikan terjadinya ambiguitas orientasi sistem budaya organisasi pada UK. Karena ciri budaya consistency menunjukkan dinamika internal organisasi, cenderung melakukan pengendalian ketat yang bertujuan untuk stabilitas internal, serta kurang dinamis dalam berinteraksi dengan lingkungan 
eksternalnya. Sementara, ciri budaya adaptability menggambarkan dinamika organisasi yang memfokuskan hubungan antara organisasi dengan lingkungan eksternalnya. Ciri budaya organisasi ke arah adaptability mengindikasikan bahwa UK memiliki fleksibilitas organisasi terhadap lingkungan eksternalnya.

Tabel 3.

Pengaruh Variabel Bebas dan Terikat Model Struktural Budaya Organisasi dan Kinerja UK

\begin{tabular}{|c|c|c|c|c|c|c|}
\hline $\begin{array}{c}\text { Variabel } \\
\text { terikat }\end{array}$ & & Variable bebas & $\begin{array}{c}\text { Loading } \\
\text { factors }\end{array}$ & C.R. & $\mathbf{P}$ & Label \\
\hline Consistency & $<<--$ & Budaya Organisasi & .87 & fix & & Signifikan \\
\hline Adaptability & \begin{tabular}{c|}
$<---$ \\
\end{tabular} & "Budaya Organisasi & .81 & 9.518 & **** & Signifikan \\
\hline Mission & $<<--$ & Budaya Organisasi & .72 & 9.235 & $* * *$ & Signifikan \\
\hline Involvement & $\begin{array}{l}<--- \\
\end{array}$ & "Budaya Organisasi & .69 & 9.362 & **** & "Signifikan \\
\hline Kinerja & $\begin{array}{l}<--- \\
\end{array}$ & " Budaya Organisasi & . .33 & 4.940 & "*** & "Signifikan \\
\hline
\end{tabular}

Rendahnya loading factor budaya organisasi terhadap kinerja UK sebesar 0,33 mencerminkan lemahnya pengaruh budaya organisasi terhadap kinerja UK (Tabel 3). Temuan ini mengindikasikan bahwa telah terjadi dysfuctional culture karena kecenderungan budaya "kuat", dimana semua loading factors ciri budaya organisasi di atas 0,69 pada UK hanya mampu menghasilkan kinerja penjualan "agak tinggi” dengan laba kecil, kinerja pertumbuhan penjualan agak naik, kinerja posisi persaingan agak naik, dan kinerja atas penyerapan tenaga kerja cenderung stabil. Ciri budaya organisasi yang mencakup involvement, consistency, adaptability, dan mission cenderung berkembang secara tidak sengaja atau berkembang secara alami, sehingga menghasilkan kinerja sebagaimana yang tidak diharapkan. Situasi ini mungkin selaras dengan apa yang dikemukakan oleh Kotter dan Heskett (1992) yang menyatakan bahwa terdapat hubungan positip, tetapi tidak kuat antara budaya organisasi dengan kinerja ekonomi jangka panjang. Kotter dan Heskett (1992) menyatakan bahwa budaya kuat menciptakan kinerja superior nampaknya hanya suatu ilusi belaka. 
Tabel 4.

Loading Factor dan Construct Validity Variabel Budaya Organisasi

\begin{tabular}{|c|c|c|c|c|c|}
\hline Ciri budaya & Factors & Loading Factor & VE & CR & $\mathbf{C A}$ \\
\hline \multirow{3}{*}{ Involvement } & Capability Development & .68 & \multirow{3}{*}{0,57} & \multirow{3}{*}{0,89} & \multirow{3}{*}{0,81} \\
\hline & Team orientation & .85 & & & \\
\hline & Empowerment & .67 & & & \\
\hline \multirow{3}{*}{ Consistency } & Core value & .80 & \multirow{3}{*}{0,58} & \multirow{3}{*}{0,89} & \multirow{3}{*}{0,82} \\
\hline & Agreement & .80 & & & \\
\hline & Coordination and integration & .66 & & & \\
\hline \multirow{3}{*}{ Adaptability } & Organizational learning & .74 & \multirow{3}{*}{0,53} & \multirow{3}{*}{0,87} & \multirow{3}{*}{0,79} \\
\hline & Customer focus & .75 & & & \\
\hline & Creating change & .69 & & & \\
\hline \multirow{3}{*}{ Mission } & Goals and objectives & .66 & \multirow{3}{*}{0,50} & \multirow{3}{*}{0,86} & \multirow{3}{*}{0,81} \\
\hline & Strategic direction & .79 & & & \\
\hline & Vission & .78 & & & \\
\hline
\end{tabular}

Lemahnya pengaruh budaya organisasi terhadap kinerja UK dapat dijelaskan dari setiap ciri budaya. Ciri budaya involvement adalah derajad dimana para individu di dalam organisasi didorong untuk merasa ikut memiliki dan rasa tanggungjawab, serta dilibatkan atau terlibat dalam mewujudkan missi dan bekerjasama dalam menjalankan pekerjaannya untuk mencapai sasaran-sasaran organisasi (Adkins dan Steward 1999). Faktor capability development yang diukur berdasarkan upaya peningkatan ketrampilan kerja dan kewenangan karyawan mengambil keputusan tentang pekerjaannya loading factor-nya lebih dominan dibanding dengan faktor empowerment yang diukur berdasar keterlibatan karyawan dalam pekerjaan, dan keyakinan karyawan tentang perannya dalam perusahaan. Hal ini mengindikasikan bahwa para pemilik UK cenderung kurang percaya dengan kemampuan para karyawannya membuat keputusan penting tentang pekerjaannya, serta cenderung mengeksploitasi karyawan sebagai faktor produksi. Pemilik UK cenderung kurang memberi kewenangan kepada karyawan untuk mengambil inisiatif dan mengembangkan kemampuannya dalam mengelola pekerjaannya. Situasi ini mengindikasikan bahwa para pemilik UK kurang bisa memanfaatkan secara penuh kemampuan dan ketrampilan para karyawannya. Karyawan yang memiliki kemampuan mungkin merasa terhalang atau frustrasi bahwa ketrampilan atau pengetahuannya tidak bisa dimanfaatkan secara penuh oleh pemilik UK, dan mungkin akan mendorong karyawan mencari peluangpeluang yang lebih baik di tempat lain. Team Orientation memiliki loading factor paling dominan dalam ciri budaya involvement dibanding faktor empowerment dan faktor capability development. Hal ini mengindikasikan bahwa para pemilik UK lebih menekankan kepada kepatuhan karyawan, dalam menjalankan pekerjaan dilakukan secara kooperatif untuk menuju 
tujuan bersama. Situasi seperti ini dapat berakibat pada rendahnya komitmen karyawan terhadap perusahaan.

Ciri budaya consistency adalah nilainilai inti dan sistem internal organisasi yang mendukung penyelesaian masalah, efisiensi, dan efektivitas setiap tingkatan dan lintas fungsi dalam organisasi (Adkins and Steward, 1999). Dilihat dari faktor-faktor ciri budaya consistency mengindikasikan bahwa UK yang disurvei mencerminkan organisasi yang efektif dan cenderung memiliki budaya kuat karena semua loading factors-nya di atas 0,66. Ciri budaya "consistency" berkaitan dengan nilai-nilai inti dan sistem internal organisasi yang mendukung penyelesaian masalah, efisiensi, dan efektivitas di dalam organisasi. Organisasi yang kuat pada ciri budaya consistency merupakan refleksi organisasi yang lebih menekankan pada stabilitas internal organisasi dan kurang menggambarkan interaksi dengan lingkungan eksternalnya. Asumsi-asumsi dasar ciri budaya consistency adalah bahwa lingkungan dapat dikelola dengan baik melalui kerja kelompok dan pengembangan karyawan, pelanggan adalah partner utama perusahaan, perusahaan berusaha mengembangkan lingkungan kerja yang humanis, dan tugas utama manajemen adalah memberdayakan karyawan dan memfasilitasi partisipasi, komitmen, dan loyalitas.

Faktor agreement dan core value memiliki loading factor yang lebih dominan atas faktor coordination and integration mengindikasikan bahwa budaya organisasi UK sedang berada pada pondasi budaya kuat. Sehingga dapat dikatakan bahwa ciri budaya consistency memberikan pondasi yang kuat pada budaya organisasi UK. Namun, yang menjadi pertanyaan berikutnya adalah apakah kuatnya pondasi ciri budaya consistency pada UK mampu mendorong kinerja yang diinginkan, baik untuk jangka pendek maupun jangka panjang. Kuatnya faktor core values dan faktor agreement mengindikasikan bahwa UK telah memiliki intensi yang baik untuk mencapai kesepakatan dan rekonsiliasi dalam isu-isu kritis bila terjadi perbedaan pendapat dan/atau kepentingan antara pemilik dan karyawan. UK memiliki kemampuan untuk menjaga stabilitas dan integrasi internal karena antara pemilik dan karyawan memiliki pikiran yang sama dan derajad kesesuaian yang tinggi. Dilihat dari ciri budaya consistency mengindikasikan bahwa UK sebagai tempat yang bersahabat untuk bekerja dimana pemilik dan karyawan kurang begitu memikirkan dirinya sendiri, seperti berada dalam lingkungan keluarga sendiri. Pemilik UK menempatkan diri sebagai mentor dan bahkan sebagai figur orang tua. Organisasi dipelihara bersama antara pemilik dan karyawan melalui loyalitas atau tradisi bersama untuk memiliki komitmen yang tinggi, menekankan teamwork, partisipasi, dan konsensus.

Ciri budaya adaptability adalah kemampuan perusahaan untuk melihat dan merespon perubahan lingkungan eksternal, terutama perubahan kebutuhan pelanggan dan stakeholders lainnya ke dalam tindakan nyata (Adkins dan Steward, 1999). Tabel 4 menunjukkan faktor customer focus memiliki loading factor lebih dominan terhadap faktor organizational learning mengindikasikan bahwa UK kemungkinan dalam situasi operasi terbaiknya dan memiliki kemampuan menciptakan standar baru di dalam industri. Namun, pada saat yang bersamaan, UK menghadapi situasi sulit dalam menerapkan pengetahuan tentang konsumen dan pasar yang diperolehnya ke dalam operasi perusahaan sehari-hari. Karena pengetahuan bersumber dari dalam perusahaan sendiri dan bukan bersumber dari pelanggan atau pasar. Dari sudut pandang ciri budaya adaptability, UK cenderung 
kurang tepat dalam memahami dan memenuhi kebutuhan pelanggan, atau besar kemungkinan UK kurang sigap dalam menghadapi apa yang dibutuhkan atau diinginkan pelanggan di masa mendatang. UK cenderung menerapkan pendekatan pasif atau kecenderungan status quo terhadap customer focus. UK cenderung bersifat menunggu pembeli datang (buyer's market). Kemampuan beradaptasi dan daya tanggap UK terhadap perubahan lingkungan relatip baik, namun kurang memiliki kemampuan untuk menciptakan standar baru di dalam industri dimana UK beroperasi. Karena faktor creating change memiliki loading factor paling lemah dibanding dengan customer focus dan organizational learning.

Ciri budaya mission adalah derajad dimana organisasi dan para anggotanya mengetahui arah kemana mereka akan menuju, bagaimana mereka akan mencapainya, dan bagaimana setiap individu dapat memberikan kontribusi terhadap keberhasilan organisasi (Adkins dan Steward, 1999). Tabel 4 menunjukkan loading factor dari strategic direction and intent dan loading factor dari vision lebih dominan dari loading factor goals and objectives. Dominannya faktor strategic direction and intent dan faktor vision, serta lebih lemahnya faktor goals and objectives mengindikasikan bahwa UK yang disurvei mengalami masa-masa sulit dalam melaksanakan atau mengimplementasikan misi dan strateginya. Situasi ini mengindikasikan diperlukannya kemampuan manajerial yang memiliki visi brilian dari pemilik UK agar mampu mengatasi masa sulit dalam menterjemahkan atau mengimplementasikan visi dan strategic direction ke dalam tindakan nyata, sehingga tujuan dan sasaran (goals and objectives) UK kurang dapat tercapai.

UK telah merumuskan goals and objectives, baik yang terjadi karena sengaja dikembangkan atau berkembang sendiri secara alami untuk menuju masa depan yang lebih baik. Namun demikian, faktor vision yang diukur berdasarkan jangkauan pemikiran ke depan, dan memenuhi tuntutan jangka pendek tanpa mengabaikan jangka panjang, dan faktor strategic direction and intent yang diukur berdasarkan kejelasan misi, dan kejelasan strategi ternyata lebih dominan dibanding dengan faktor goals and objectives yang diukur berdasarkan penetapan tujuan, dan pemahaman karyawan pada tujuan perusahaan. Temuan ini mengindikasikan bahwa karyawan UK kurang memahami apa yang menjadi tujuan perusahaan dan pada akhirnya tujuan perusahaan tidak tercapai sebagaimana yang diharapkan.

Budaya organisasi pada Usaha Kecil (UK) berkembang budaya "kuat" yang cenderung ke arah ciri budaya consistency dan ciri budaya adaptability. Kuatnya ke arah ciri budaya consistency dan ciri budaya adaptability mengindikasikan terjadinya ambiguitas orientasi sistem budaya organisasi pada UK. Ciri budaya consistency menunjukkan dinamika internal organisasi yang cenderung melakukan pengendalian ketat yang tujuannya untuk stabilitas internal, serta kurang dinamis dalam berinteraksi dengan lingkungan eksternalnya. Sementara, ciri budaya adaptability menggambarkan dinamika organisasi yang memfokuskan pada fleksibilitas hubungan antara organisasi dengan lingkungan eksternalnya. Ciri budaya organisasi ke arah adaptability mengindikasikan bahwa UK memiliki fleksibilitas organisasi terhadap lingkungan eksternalnya. Ambiguitas orientasi system budaya berakibat pada lemahnya pengaruh budaya organisasi terhadap kinerja UK.

Para pemilik UK perlu menciptakan perasaan persamaan identitas, harapan, dan perilaku dengan para karyawannya melalui 
peraturan atau pedoman yang jelas dan konsisten yang lebih peduli terhadap orang dan proses agar mampu mendukung penyelesaian masalah, efektifitas, serta efisiensi perusahaannya. Pemilik UK perlu menciptakan perubahan yang bermanfaat bagi perusahaan dengan cara lebih peduli kepada para pelanggan dan karyawannya. Disamping itu, para pemilik UK perlu mencoba mengawali perubahan bila diperlukan untuk berubah dalam rangka memproleh keunggulan kompetitif sekalipun hal tersebut (mengawali perubahan) mengandung banyak risiko. Namun, para pemilik UK perlu menyadari bahwa secara alamiah ada kecenderungan dari budaya yaitu adanya kecenderungan menolak perubahan walaupun lingkungan berubah secara drastis.

Para pemilik UK perlu merumuskan visi, misi, dan arah perusahaannya secara jelas. Kemudian visi, misi, dan arah perusahaann tersebut dikomunikasikan dengan kata-kata yang sederhana, langsung, sering, dan perilaku atau perbuatan nyata dari pemilik kepada para karyawannya. Dengan mengkomunikasikan visi dan misi secara intensif dan masif, maka para karyawan akan memiliki perspektif atau pandangan yang sama tentang perusahaan, memiliki nilai-nilai yang sama tentang perusahaan, dan dapat menumbuhkan kesadaran karyawan bahwa mereka adalah bagian dari perusahaan.

\section{KESIMPULAN}

Hasil penelitian mengindikasikan bahwa budaya organisasi berpengaruh positip dan signifikan terhadap kinerja Usaha Kecil (UK). Dalam penelitian ini, teori yang digunakan untuk mengukur budaya organisasi pada UK adalah Denison Organizational Culture Survey (DOCS). Penelitian menemukan bahwa budaya organisasi yang diukur berdasarkan DOCS memiliki pengaruh lemah terhadap kinerja UK. Sementara terdapat berbagai teori yang mengkaji dan menggolongkan ciri budaya organisasi, missal: Sonnenfeld (1998) dalam Sadri dan Lees (2001) menggolongkan empat tipe budaya organisasi, yaitu: akademi, klub, tim baseball, dan benteng (fortress); Lomas (1999) menggolongkan budaya organisasi menjadi empat golongan, yaitu budaya kolegial, budaya birokratik, budaya entrepreneurial, dan budaya korporat; Cornwall (1990) membedakan 2 (dua) tipe budaya organisasi, yaitu budaya organisasi tradisional (traditional organizational culture) dan budaya organisasi entrepreneurial (entrepreneurial organizational culture); Cameron dan Quinn (1999) menggolongkan budaya organisasi ke dalam empat jenis, yaitu Budaya Marga (Clan Culture), Budaya Adhokrasi, Budaya Hirarkhi, dan Budaya Pasar. Karena itu, apakah temuan penelitian ini tetap konsisten bila dikaji atau diuji dengan menggunakan teori tentang ciri budaya organisasi selain DOCS pada UK. Penelitian tentang budaya organisasi pada UK di masa mendatang perlu dikaji dari berbagai perspektif teori tersebut.

Kinerja perusahaan merupakan fenomena multi-aspek yang sulit diukur. Dalam penelitian ini kinerja UK diukur berdasarkan skala "sikap" menurut Gupta dan Govindarajan (1984) dalam Kotey dan Meredith (1997) yang mencakup penilaian responden berdasarkan skala Likert terhadap ukuran-ukuran kinerja perusahaan kecil. Menurut Kotey dan Meredith (1997) metode pengukuran kinerja Gupta dan Govindarajan ternyata memiliki tingkat reliabilitas dan validitas yang tinggi, hal ini merefleksikan keakuratan pengukuran kinerja perusahaan. Namun, agenda penelitian ke depan perlu dipertimbangkan penggunaan ukuran-ukuran kinerja UK yang bersifat kuantitatip yang mencakup, misal: tingkat penjualan, tingkat pertumbuhan penjualan, arus kas, tingkat 
pengembalian modal sendiri, margin laba kotor, laba bersih operasi, rasio laba atas penjualan, tingkat pengembalian modal, kemampuan membiayai pertumbuhan perusahaan dari laba, serta kinerja secara keseluruhan. 


\section{DAFTAR PUSTAKA}

Adkins, Bryan, Sr. and Steward, Cindy. 1999). Shift Organizational Culture to Improve Organizational Performance.badkins@denisonculture.com

Barney, J. B. 1986. "Organizational culture: Can it be a source of sustained competitive advantage?" Academy of Management Review, Vol. 11; 656-665.

Cameron, Kim S. and Robert E. Quinn. 1999. Diagnosing and Changing Organizational Culture, Base on the Competing Values Framework. New York : Addison-Wesley.

Choueke, Richard, and Armstrong, Roger. 2000.” Culture: a Missing Perspective on Small and Medium Sized Enterprise”. International Journal of Entrepreneurial Behavior \& Research, Vol. 6, No. 4, 227-238

Cornwall, Jeffrey R.; Perlman, Baron. 1990. Organizational Entrepreneurship. Boston : Richard D. Irwin, Inc.

Cunha, Rita Campos E., Cunha, Miguel Pina E., Market Forces. Strategic Management, HRM Practices and Organizational Performance, A Model Based in a European Sample. rcunha@fe.unl.pt

Deal, T., \& Kennedy, A. 1982. Corporate Culture. Canada: Addison-Wesley.

Denison, D. 1990. Corporate Culture and Organisational Effectiveness. New York: John Wiley \& Sons.

Denison, D. 2000. “Organisational culture: Can it be a key for lever for driving organisational change?”. The International handbook of organisational culture and climate (347-376). Chichester: John Wiley \& Sons.

Denison, Daniel R.; Neale. 1982. Denison Organizational Culture Survey. Washington :Denison Consulting LLC.

Fey, Carl F.; Denison, Daniel R. 2000. Organizational Culture and Effectiveness: the Case of Foreign Firms in Russia. iibcf@hhs.se and ddenison@umich.edu

Hofstede, Geert, and McCrae, Robert R. 2004. Personality and Culture Revisited: Linking Traits and Dimensions of Culture. The Netherlands : Institute for Research on Intercultural Cooperation Tilburg.hofstede@bart.nl

Kandula, S. R. 2006. Performance Managemen t. New Delhi: Prentice Hall of India private limited.

Kinnear, Thomas C.; Taylor, James R. 1997. Riset Pemasaran, Edisi Ketiga. Jakarta: Penerbit Erlangga.

Kotey, Bernice; and Meredith, G.G. 1997. "Relationships among Owner/Manager Personal Values, Business Strategies, and Enterprise Performance”. Journal of Small Business Management, 37-61

Kotter, John P., dan Heskett, James L. 1992. Dampak Budaya Perusahaan terhadap Kinerja. Jakarta :, PT. Prenhallindo.

Lomas, Laurie. 1999. The Culture and Quality of Higher Education Institutions: Examining the Link, Quality Assurance in Education Volume 7 Number 1. 30-34

McGarvy, E., and Wolfe, R. 2000. Virginia childhood prevention project. Organisational assessment report. http: www.findarticles/p/articles

Musselwhite, C. 1999. The performing culture. Retrieved February 22, 2006, http: www.findarticles.com/p/articles

Newstrom, John W., and Davis, Keith. 2002. Organizational Behavior, Human Behavior at Work, McGraw-Hill Irwin Company

Nier, S. 2004. Defense logistics agency: Human resources strategy. Retrieved February 22, 2006, from http: www.DLAarticles.com

Paige, Rosalind C. 2005. “An Examination of The Relationship Among Organizational Values, Strategies, Key Success, Skill, Culture and Performance of Micro-Businesses”. Academy of Entrepreneurship Journal, Volume 11 Number 1, 35-57

Rashid, Zabid Abdul; Sambasivan, Murali; and Johari, Juliana. 2003. "The Influence of Corporate Culture and Organizational Commitment on Performance,”.Journal of Management Development Vol. 22 No. 2, 708-728 
Pengaruh Budaya Organisasi ... (Rohmat D. J.)

Sadri, Golnaz; and Lees, Brian. 2001. "Developing Corporate Culture as a Competitive Advantage”. Journal of Management Development, Vol. 20, No. 10, 853-859

Salama, Alzira; and Smith, Mark Easterby. 1994. "Cultural Change and Managerial Careers". Personal Review, Vol. 23, No. 3, pp.21-33

Sanchez, Antonio Aragon; Marin, Gregorio-Sanchez. 2005. "Strategic Orientation, Management Characteristics, and Performance: A Study of Spanish SMEs". Journal of Small Business Management, Vol. 43, No, 3. pp. 287-306

Schein, Edgar H. 1992. Organizational Culture and Leadership, Second edition. San Francisco: HosseyBass Publishers.

Scott, T., Mannion, R., Davies, H., \& Marshall, M. 2003. "The quantitative measurement of organisational culture in health care: A review of the available instruments". Health Services Research, 38(3), 923-945.

Simpson, Steve; and Cacioppe, Ron. 2001. "Unwritten Ground Rules: Transforming Organization Culture to achieve Key Business Objectives and Outstanding Customer Service”. Leadership \& Organization Development Journal, 22/8, 394-401

Suda, Lawrence. 2007. Linking Strategy, Leadership and Organization Culture for Project Success. Palatine Group/Management Worlds

Turunen, Tiina. 2007. Organizational Culture as a Basis for a Sustainable Competitive Advantage. Tu91.167

Van den Steen, E. J. 2005. “Organizational beliefs and managerial vision”. Journal of Law, Economics, and Organization, vol. 21(1). 256-283.

Verreynne, Martie-Louise. 2005. "Strategy-Making Process and Firm Performance in Small Firms". Research Paper Series. Faculty of Business, AUT, ISSN Number 1176-1997

Zwaan, Leigh Angy. 2006. Assessing Organizational Culture in a Privat Hospital in the Western Cape. Department of Industrial Psychology, Faculty of Economic and Management Science, University of the Western Cape 